\title{
Fluid inclusion studies of the Chinkuashih high-sulfidation gold-copper deposits in Taiwan
}

\author{
Yunshuen Wang a,c,* , Munetake Sasaki ${ }^{\mathrm{b}}$, Masakatsu Sasada ${ }^{\mathrm{b}}$, Cheng-Hong Chen ${ }^{\mathrm{c}}$ \\ ${ }^{\text {a }}$ Central Geological Survey, P.O. Box 968, Taipei, Taiwan, ROC \\ ${ }^{\mathrm{b}}$ Geological Survey of Japan, Tsukuba, Ibaraki, 305 Japan \\ ${ }^{c}$ Department of Geology, National Taiwan University, Taipei, Taiwan, ROC
}

\begin{abstract}
Epithermal high-sulfidation $\mathrm{Au}-\mathrm{Cu}$ deposits at Chinkuashih in northeastern Taiwan are found both within Pleistocene calc-alkaline volcanic rocks and the Miocene sedimentary rocks. The deposits consist of gold-copper veins of the Penshan group and breccia pipes of the Tushihshan-Changjen group. Primary two-phase inclusions in hydrothermal quartz and secondary two-phase inclusions in hydrothermal quartz as well as igneous quartz phenocrysts probably represent fluids related to mineralization. These inclusions have homogenization temperatures generally between $190^{\circ} \mathrm{C}$ and $280^{\circ} \mathrm{C}$ and salinities mostly from $0.5-5.0 \mathrm{wt} . \% \mathrm{NaCl}$ eq. In the Penshan group, microthermometric data indicate that variable amounts of boiling, mixing and cooling occurred in the hydrothermal system. Based on the Th of inclusions trapped from boiling fluids and the $\mathrm{CO}_{2}$ contents of the inclusions, the hydrostatic pressure is estimated at 6.9-7.9 MPa. In the TushihshanChangjen group, the microthermometry of sulfur gas-bearing secondary two-phase fluid inclusions from hydrothermal quartz shows bimodal contents for a certain Th value, perhaps due to the intermittent incursion of brine at depth by phreatic or phreato-magmatic explosions. The presence of poly-phase (liquid + vapor + halite \pm sylvite \pm opaques) fluid inclusions with high $\mathrm{Th}\left(307^{\circ} \mathrm{C}-484^{\circ} \mathrm{C}\right)$ and high salinities $(30-51 \mathrm{wt} . \% \mathrm{NaCl}$ eq.) in one sample suggests a dense brine of probable magmatic derivation circulated in the Chinkuashih system. Halite-bearing inclusions which were homogenized by vapor disappearance coexisting with low-salinity vapor-rich inclusions in this sample may have been trapped in an immiscibility field at vapor-pressures from 7.5 to $21.5 \mathrm{MPa}$. Halite-bearing inclusions which were homogenized by halite dissolution after the vapor disappearance may have been trapped under even greater pressures. Fluid inclusion gas in samples were analyzed with a QMS. The results of bulk analyses indicate that these inclusions contain 99.45-99.67 mol\% $\mathrm{H}_{2} \mathrm{O}, 0.27-0.52 \mathrm{~mol} \%$ $\mathrm{CO}_{2}, 0.015-0.066 \mathrm{~mol} \% \mathrm{~N}_{2}, 0.0015-0.015 \mathrm{~mol} \% \mathrm{CH}_{4}$ and small amounts of $\mathrm{SO}_{2}$ in three samples. These data suggest that the inclusion fluids are dominantly meteoric waters that interacted with host rocks and accumulated upward-fluxing magmatic volatiles. The fluid inclusion data indicate that the hydrothermal fluids related to the ore deposition of the high sulfidation $\mathrm{Au}-\mathrm{Cu}$ deposits at Chinkuashih are characterized by the interaction of magmatic fluids with meteoric water under epithermal conditions. (c) 1999 Elsevier Science B.V. All rights reserved.
\end{abstract}

Keywords: Gold; Copper; Fluid inclusion

\footnotetext{
*Corresponding author. E-mail: wangys@linx.moeacgs.gov.tw
} 


\section{Introduction}

Pleistocene gold-copper deposits are found in the Chinkuashih district in northeastern Taiwan (Fig. 1). Ninety-two tons of gold, 119,101 tons of copper and 183 tons of silver were produced from about 20 million tons of ore between 1898 and 1987 (Tan, 1991). Tectonically, Chinkuashih is situated along the western extension of the Ryukyu volcanic arc which was formed by the subduction of the Philippine Sea plate beneath the Eurasian plate. The Chilung volcanic group, which is related to mineralization, represents the western extension of the volcanic arc in the Ryukyu arc system. The igneous rocks are mainly augite-bearing biotite hornblende dacite and two pyroxene biotite hornblende dacite of
Pleistocene age (Chen and Huh, 1982). They occur as small intrusive sills, bodies and dikes as well as extrusive lavas and tuffs in or on interbedded sandstone and shales of Miocene age. Intense hydrothermal alteration and mineralization occur both within the dacite and in the surrounding sedimentary rocks.

Ore deposits in the Chinkuashih area include gold-copper veins of the Penshan group in the center of this district, breccia pipes of the Tsushihshan-Changjen group to the east of Penshan and gold veins of the Chiufen-Wutanshan group to the west of Penshan (Tan, 1991). Mineralogic and geochemical characteristics indicate that the Penshan and Tsushihshan-Changjen groups are similar to 'high-sulfidation' (Hedenquist, 1987) or 'acidsulfate' (Heald et al., 1987) types of deposit, whereas

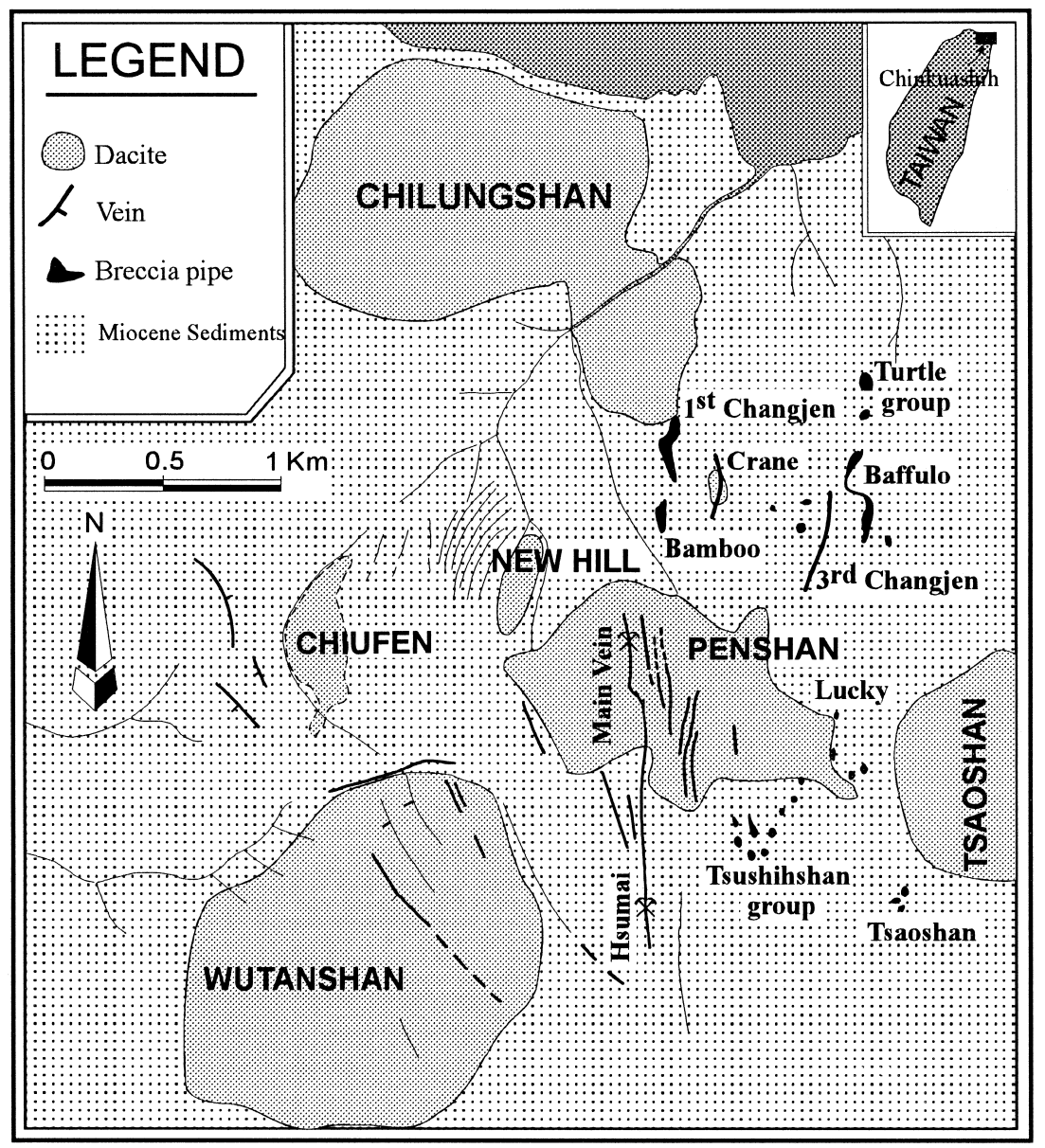

Fig. 1. Map of the Chinkuashih area showing the distribution of rock types and the location of $\mathrm{Au}-\mathrm{Cu}$ deposits. 
the Chiufen-Wutanshan groups show an affinity to 'low-sulfidation' (Hedenquist, 1987) or 'adulariasericite' (Heald et al., 1987) types.

Pliocene-Quaternary normal faults resulting from the oblique convergence between the Philippine Sea plate and the Eurasian plate were important conduits of ascending hydrothermal solutions which led to the formation of the ore deposits. The most important ore-vein, the 'Main Vein' of the Penshan group is mineralized along the north-south normal faults.

In this paper, fluid inclusion microthermometric measurements were used to provide information on temperature, pressure and salinity and to document the evolution of high-sulfidation epithermal fluids. Low-sulfidation systems were excluded due to the paucity of samples. Particular attention was paid to the characteristics of the magmatic contribution during hydrothermal activity and mineralization. Fluid inclusion gases were also analyzed in an attempt to elucidate fluid-rock interaction processes and physico-chemical conditions of hydrothermal fluids.

\section{Method of study}

Doubly polished thin sections, approximately 100 $\mu \mathrm{m}$ thick, were prepared from more than 50 quartz and barite samples for preliminary petrographic study. From these, 29 samples containing representative populations of inclusions were then selected for detailed analysis. The homogenization temperature (Th) and ice-melting temperature $(\mathrm{Tm})$ were measured for approximately 700 fluid inclusions. Microthermometric studies were performed using a Fluid Inc-adapted U.S.G.S. gas flow heating and freezing system. The data are reproducible to $\pm 2^{\circ} \mathrm{C}$ for heating runs and $\pm 0.2^{\circ} \mathrm{C}$ for freezing runs. Homogenization temperatures were collected only from inclusions within a growth zone or an isolated plane, which exhibited consistent liquid-to-vapor volumetric ratios. Fluid inclusions in barite both from goldcopper veins of the Penshan group and breccia pipes of the Tushihshan-Changjen group may have resulted from later necking processes and were therefore excluded from this study. No liquid $\mathrm{CO}_{2}$ or evidence of clathrate formation was detected in any of the samples after being frozen.

The gas composition of fluid inclusions were analyzed with a rapid-scanning quadrupole mass spectrometer in the laboratories of the Geological Survey of Japan. Sample preparation and analytical processes were followed according to Sasada et al. (1992).

\section{Gold-copper veins of the Penshan group}

\subsection{Geology and mineralization}

The northern portion of the gold-copper veins of the Penshan group is hosted by dacite and is known

Table 1

Characteristics of epithermal high-sulfidation Chinkuashih $\mathrm{Au}-\mathrm{Cu}$ deposits

\begin{tabular}{|c|c|c|c|c|c|}
\hline \multirow{2}{*}{$\begin{array}{l}\text { Group name } \\
\text { Deposit type }\end{array}$} & \multicolumn{2}{|l|}{ Penshan } & \multicolumn{3}{|c|}{ Tushihshan-Changjen } \\
\hline & $\mathrm{Au}-\mathrm{Cu}$ veins & & Breccia pipes & & \\
\hline $\begin{array}{l}\text { Orebody name } \\
\text { Host lithologies } \\
\text { Alteration type }\end{array}$ & $\begin{array}{l}\text { Penshan } \\
\text { dacite } \\
\text { silicic } \\
\text { advanced argillic } \\
\text { argillic } \\
\text { propylitic }\end{array}$ & $\begin{array}{l}\text { Hsumei } \\
\text { sandstone } \\
\text { silicic } \\
\text { advanced argillic } \\
\text { argillic }\end{array}$ & $\begin{array}{l}\text { First Changjen } \\
\text { sandstone dacite } \\
\text { silicic } \\
\text { advanced argillic } \\
\text { argillic }\end{array}$ & $\begin{array}{l}\text { Third Changjen } \\
\text { sandstone } \\
\text { silicic } \\
\text { advanced argillic } \\
\text { argillic }\end{array}$ & $\begin{array}{l}\text { Buffalo } \\
\text { sandstone shale } \\
\text { silicic } \\
\text { advanced argillic } \\
\text { argillic }\end{array}$ \\
\hline Age (Ma) & $1.0 \pm 0.1^{\mathrm{A}}$ & - & - & $0.96 \pm 0.01^{\mathrm{B}}$ & - \\
\hline
\end{tabular}

${ }^{\mathrm{A}} \mathrm{K}-\mathrm{Ar}$ dating of alunite was proposed by Chen et al. (1993).

${ }^{\mathrm{B} 40} \mathrm{Ar}-{ }^{39} \mathrm{Ar}$ dating of alunite was proposed by $\mathrm{Yu}$ (1994). 
Table 2

Summary of microthermometric results for fluid inclusions of the Chinkuashih deposits

\begin{tabular}{|c|c|c|c|c|c|c|c|c|c|}
\hline Deposit name & $\begin{array}{l}\text { Sample } \\
\text { no. }\end{array}$ & $\begin{array}{l}\text { Host } \\
\text { mineral }\end{array}$ & $\begin{array}{l}\text { Elevation } \\
\text { (m) }\end{array}$ & $\begin{array}{l}\text { F.I. } \\
\text { type }\end{array}$ & $\begin{array}{l}\text { F.I. } \\
\text { character }\end{array}$ & Th $\left({ }^{\circ} \mathrm{C}\right)$ range & $\begin{array}{l}\text { Th }\left({ }^{\circ} \mathrm{C}\right) \\
\text { avg. }\end{array}$ & $\begin{array}{l}\text { wt. } \% \mathrm{NaCl} \\
\text { eq. range }\end{array}$ & $\begin{array}{l}\text { wt.\% } \mathrm{NaCl} \\
\text { eq. avg. }\end{array}$ \\
\hline \multirow[t]{13}{*}{ Penshan } & 212 & H-Qtz & 380 & Ia & $\mathrm{P}$ & $254-288(11)$ & 271 & $1.4-2.6(11)$ & 1.8 \\
\hline & 214 & H-Qtz & 425 & Ia & $\mathrm{S}$ & $213-248(22)$ & 230 & $1.7-3.2(22)$ & 2.4 \\
\hline & 215 & H-Qtz & 425 & Ia & $\mathrm{P}$ & $242-260(5)$ & 255 & $1.1-1.2(3)$ & 1.1 \\
\hline & 215 & H-Qtz & 425 & Ia & $\mathrm{S}$ & $162-217(23)$ & 189 & $1.1-8.1(22)$ & 4.0 \\
\hline & 103 & I-Qtz & 495 & Ia & $\mathrm{S}$ & $211-218(5)$ & 215 & $1.6-1.7(4)$ & 1.7 \\
\hline & 104 & I-Qtz & 495 & Ia & $\mathrm{S}$ & $185-255(19)$ & 225 & $2.9-4.3(19)$ & 3.7 \\
\hline & 139 & $\mathrm{I}-\mathrm{Qtz}$ & 505 & Ia & $\mathrm{S}$ & $183-235(60)$ & 200 & $0-3.7(59)$ & 1.2 \\
\hline & 204 & H-Qtz & 520 & Ia & $\mathrm{P}$ & $264-298(7)$ & 277 & $1.1-1.4(7)$ & 1.3 \\
\hline & 205 & H-Qtz & 520 & Ia & $\mathrm{P}$ & $270-275(11)$ & 273 & $0.9-1.1(11)$ & 0.9 \\
\hline & 205 & H-Qtz & 520 & $\mathrm{Ia}$ & $\mathrm{S}$ & $232-256(9)$ & 245 & $2.7-4.0(9)$ & 3.4 \\
\hline & 206 & H-Qtz & 520 & Ia & $\mathrm{P}$ & $238-256(14)$ & 248 & $1.7-3.4(14)$ & 2.5 \\
\hline & 209 & H-Qtz & 520 & Ia & $\mathrm{P}$ & $260-272(17)$ & 269 & $1.1-1.7(17)$ & 1.5 \\
\hline & 209 & H-Qtz & 520 & Ia & $\mathrm{S}$ & $243-282(35)$ & 258 & $0.7-2.4(35)$ & 1.4 \\
\hline \multirow[t]{4}{*}{ Hsumei } & 126 & H-Qtz & 500 & Ia & $\mathrm{S}$ & $220-342(10)$ & 233 & $1.6-2.2(5)$ & 1.8 \\
\hline & 132 & H-Qtz & 500 & Ia & $\mathrm{P}$ & $240-262(9)$ & 247 & $0.9-1.4(9)$ & 1.2 \\
\hline & 132 & H-Qtz & 500 & Ia & $\mathrm{S}$ & $201-233(23)$ & 217 & $0.7-2.4(18)$ & 1.3 \\
\hline & 227 & H-Qtz & 595 & Ia & $\mathrm{S}$ & $207-247(19)$ & 231 & $1.1-1.9(19)$ & 1.5 \\
\hline \multirow[t]{3}{*}{ 1st Changien } & 174 & H-Qtz & 300 & Ia & $\mathrm{S}$ & $217-267(30)$ & 243 & $1.1-2.7(24)$ & 2.0 \\
\hline & 175 & H-Qtz & 300 & Ia & $\mathrm{S}$ & $207-258(25)$ & 235 & $2.2-4.0(25)$ & 2.9 \\
\hline & 176 & H-Qtz & 300 & Ia & $\mathrm{S}$ & $242-266(24)$ & 259 & $1.7-3.7(22)$ & 2.4 \\
\hline \multirow[t]{3}{*}{ 3rd Changien } & 202 & H-Qtz & 390 & Ia & $\mathrm{S}$ & $196-248(60)$ & 225 & $12-4.3(47)$ & 2.2 \\
\hline & 201 & H-Qtz & 550 & Ia & $\mathrm{S}$ & $206-251(45)$ & 231 & $1.1-2.7(45)$ & 1.7 \\
\hline & 182 & H-Qtz & 550 & Ia & $\mathrm{S}$ & $208-242(46)$ & 227 & $1.7-4.5(46)$ & 3.2 \\
\hline \multirow[t]{6}{*}{ Buffalo } & 160 & H-Qtz & 450 & Ia & $\mathrm{S}$ & $235-267(30)$ & 252 & $2.7-5.0(36)$ & 3.5 \\
\hline & 164 & H-Qtz & 450 & Ia & $\mathrm{P}$ & $310-372(113)$ & 342 & $0.7-12.4(109)$ & 3.8 \\
\hline & 164 & H-Qtz & 450 & $\mathrm{Ib}$ & $\mathrm{P}$ & $345-387(2)$ & 366 & $17.8-23.2(2)$ & 20.5 \\
\hline & 164 & H-Qtz & 450 & IIIa & $\mathrm{P}$ & $274-457(24)$ & 326 & $32.1-47.3(24) *$ & 40.3 \\
\hline & 164 & H-Qtz & 450 & IIIb & $\mathrm{P}$ & $342-417(6)$ & 370 & $30.3-50.7(6) *$ & 37.9 \\
\hline & 164 & H-Qtz & 450 & IIIc & $\mathrm{P}$ & $371-392(2)$ & 381 & $43.9-51.1(2) *$ & 47.5 \\
\hline
\end{tabular}

F.I. $=$ fluid inclusion, $\mathrm{Tm}=$ ice-melting temperature, $\mathrm{Th}=$ liquid-vapor homogenization temperature, number of measurements are given in brackets; all salinities are calculated from Tm except those with an asterisk which are calculated from the final melting temperature of halite. $\mathrm{H}-\mathrm{QTZ}=$ hydrothermal quartz, $\mathrm{I}-\mathrm{Qtz}=$ relic igneous quartz, $\mathrm{P}=$ primary, $\mathrm{S}=$ secondary.

as the Penshan orebody; on the other hand, the southern portion is hosted by Miocene sedimentary rocks and is referred to as the Hsumei orebody. Hydrothermal circulation affected the volcano-sedimentary sequence most during or immediately after volcanic activity. Early hydrothermal activity was responsible for acid alteration, similar to other typical high-sulfidation systems. Four hypogene alteration types of silicification, advanced argillic alteration, argillic alteration and propylitization, have

Fig. 2. Microthermometric data for fluid inclusions in quartz from the Chinkuashih area. (A) Homogenization temperatures of primary and secondary fluid inclusions in quartz from the Penshan group. (B) Average salinities (wt.\% $\mathrm{NaCl}$ eq.) versus average homogenization temperatures (Th) for genetically related populations of primary inclusions (filled circle) and secondary inclusions (open circle) in quartz from the Penshan orebody, and primary inclusions (filled triangle) and secondary inclusions (open triangle) in quartz from the Hsumei orebody of the Penshan group. (C) Homogenization temperatures of secondary fluid inclusions in quartz from the Tushihshan-Changjen group. (D) Average salinities versus average Th for genetically related populations of secondary inclusions in quartz from the Buffalo (open triangle), First Changjen (open circle) and Third Changjen (filled circle) overbodies of the Tushihshan-Changjen group. (E) Final homogenization temperatures of primary fluid inclusions in quartz from sample 164. Inclusions homogenized by either vapor bubble disappearance or halite dissolution. (F) Salinities versus final homogenization temperatures of fluid inclusions in sample 164. 
previously been recognized within dacite of the Penshan orebody (Wang, 1973). Silicification in the orebody consists of massive and vuggy silica bodies. In the Hsumei orebody, silicification, advanced
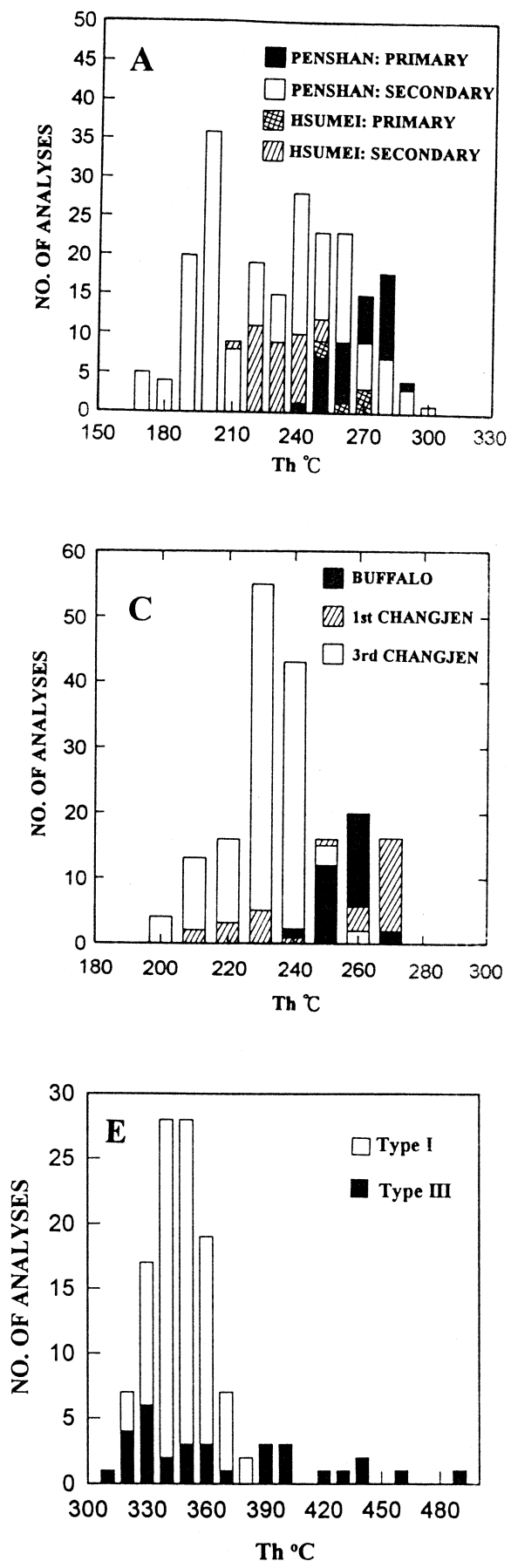

argillic alteration, and argillic alteration are well developed within the sandstone (Chen, 1971). The silicified sandstone is porous, but the original clastic structure is still preserved (Huang, 1955).
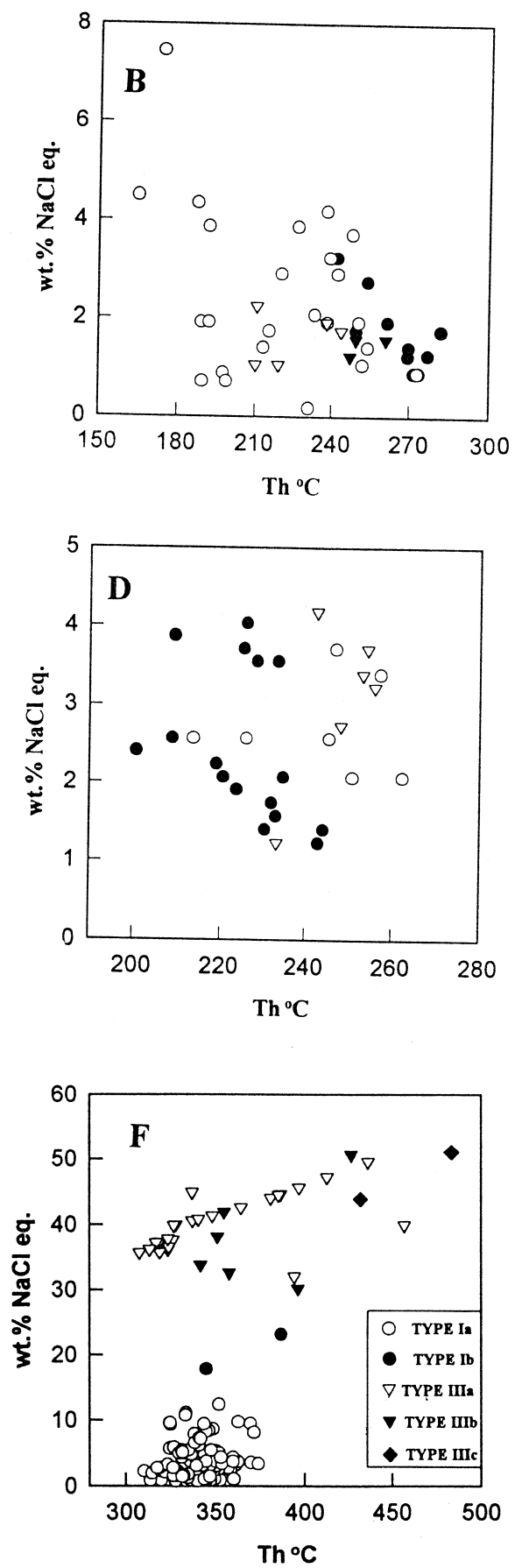
The ore stage clearly postdates hydrothermal alteration, as indicated by the occurrence of fissure filling, disseminations and stockworks in the silicification zone. Enargite and luzonite are the principal copper minerals. Gold occurs as native gold, electrum and auriferous pyrite. Locally, the sulfide assemblages are accompanied by quartz crystals. In some cases, quartz crystals lining vuggy silica cavities contain anhedral to euhedral crystal of pyrite. A late stage of hydrothermal activity led to the emplacement of barite veinlets in the surficial parts of the system. These veinlets carry gold grades. Fission track and $\mathrm{K}-\mathrm{Ar}$ age dating of the mineralization and its host igneous rocks have been proposed by Chen et al. (1993). Their studies, indicated that intrusion of the Penshan body occurred between ca. 1.4 and 1.1 Ma, whereas gold-copper mineralization of the Penshan orebody was dated at 1.0 Ma. The characteristics of the deposits are summarized in Table 1.

\subsection{Occurrence of fluid inclusions and microthermo- metric results}

Fluid inclusions in the Penshan orebody were studied in the following minerals: (1) igneous quartz phenocrysts occurring in a matrix of vuggy silica; (2) hydrothermal quartz occurring as vug-filling in the matrix of vuggy silica; and (3) hydrothermal quartz occurring as overgrowths on igneous quartz phenocryst and lining fractures and voids of vuggy silica bodies. In some cases, hydrothermal quartz crystal are associated with pyrite. Hydrothermal quartz in the Hsumei orebody occurs as euhedral crystals lining cavities and fractures of the silicified sandstone.

All the fluid inclusions contain two phases at room temperature - a liquid phase and a vapor bubble. Liquid-rich type Ia inclusions homogenize by disappearance of the vapor bubble. In contrast, vapor-rich type II inclusions have vapor bubbles filling more than 95 vol.\% of the inclusion and homogenize into the vapor. The homogenization temperatures of type II inclusions were not determined in this study owing to the difficulty involved with making visual estimations when the vapor phase filled the inclusion (Bodnar et al., 1985). Primary type Ia inclusions contain consistent liquid to vapor ratios within individual growth zones. The inclusions are usually well formed and consistent in size $(5-10 \mu \mathrm{m})$. The coexistence of type Ia and type II primary fluid inclusions in well-defined growth zones suggests that these inclusions resulted from the trapping of boiling fluids.

Secondary type Ia inclusions in healed fracture planes are abundant. They tend to be of various shapes, from irregular to subspherical to elliptical and of highly variable size, up to $45 \mu \mathrm{m}$. Some of the secondary inclusion populations contain onephase, liquid-filled inclusions accompanied by highly variable liquid-to-vapor ratios within individual healed microfractures indicating the inclusions were formed during necking processes. These inclusions were excluded during heating/freezing analyses.

The characteristics of the studied fluid inclusions and microthermometric data are summarized in Table 2. The fluid-inclusion homogenization temperatures in quartz are shown in Fig. 2A. Fig. 2B illustrates the relationship between the homogenization temperatures and salinities for genetically related populations of fluid inclusions. The apparent salinities were obtained according to Bodnar (1993).

\section{Breccia pipes of the Tushihshan-Changjen group}

\subsection{Geology and mineralization}

Breccia pipes occur east of the Penshan group, including the Tsushihshan and Changjen orebodies (Tan, 1991). Acidic wall-rock alteration was probably accompanied by phreatic and phreato-magmatic eruptions, which intersected earlier Miocene sedimentary rocks and produced the diatreme breccias of the Tushihshan-Changjen group. However, the Tsushihshan orebodies were not included in this study due to the absence of samples.

The breccia pipes have a funnel shape being 200-700 $\mathrm{m}$ in the vertical dimension and just a few up to $20 \mathrm{~m}$ in the upper diameter. Yu (1994) demonstrated that the major constituent of the fragments in the pipes is shale, although sandstone, dacite and sedimentary chalcedony with laminated structure are also present. Milled breccia fragments, sheeted fractures, collapse breccia and sedimentary structures were observed in the pipes. Yu (1994) also found the multi-layers of horizontal graded bedding within clasts within the breccia pipes in the inclined sedimentary rocks, and the clast-in-clast structure indi- 
cates that multiple series of brecciation have occurred in the same pipe.

Ore-minerals are mostly found in the fractures and pores of silicified breccias, suggesting that their deposition was subsequent to the alteration process. At a late stage, mineralization mainly consisting of barite, locally with remarkable gold grades, was deposited in the surficial parts of the system $(\mathrm{Yu}$, 1994). The ${ }^{40} \mathrm{Ar} /{ }^{39} \mathrm{Ar}$ ages from alunites indicate that the breccia pipes were formed at 1.11-0.96 Ma and mineralized at $0.96 \pm 0.01 \mathrm{Ma}(\mathrm{Yu}, 1994)$. The characteristics of the deposits are also summarized in Table 1.

\subsection{Occurrence of fluid inclusions and microthermo- metric results}

Fluid inclusion data were obtained from hydrothermal quartz of the Buffalo, First Changjen and Third Changjen orebodies. The quartz from the three orebodies occurs as euhedral crystals lining fractures in the silicified sediments. The quartz might have been deposited after an initial leaching event, with most of the crystals being syn-sulfide deposition. In some cases, quartz crystals lining cavities contain anhedral to subhedral enargite. Most of the fluid inclusions in the hydrothermal quartz from the group occur as secondary inclusions in healed fracture planes. Primary fluid inclusions cannot be identified. These secondary fluid inclusions are irregular in shape, with size ranging from 1 to $10 \mu \mathrm{m}$. Two-phase liquid-rich (type Ia) and two-phase vapor-rich (type II) inclusions make up the only two types of inclusions. Type II inclusions are common, but some of them probably resulted from necking.

A summary of the microthermometric results for fluid inclusions of the hydrothermal quartz are presented in Table 2. Fluid-inclusion homogenization temperatures in the hydrothermal quartz from the three orebodies are shown in Fig. 2C. A diagram of salinities (wt.\% $\mathrm{NaCl}$ eq.) versus $\mathrm{Th}$ is shown in Fig. 2D. There, the salinities of inclusions from the Buffalo orebody show a large variation at a narrow homogenization temperature range, while the salinities of inclusions from the first Changjen and Third Changjen orebodies occur as two clusters in different domains at certain Th values.

In one sample, namely, no. 164 from the Buffalo orebody, quartz crystals $(0.5-3 \mathrm{~mm}$ long) occur as cement within porous residual silica. Each quartz crystal contains fluid inclusions. Three major types of these inclusions are identified in terms of their

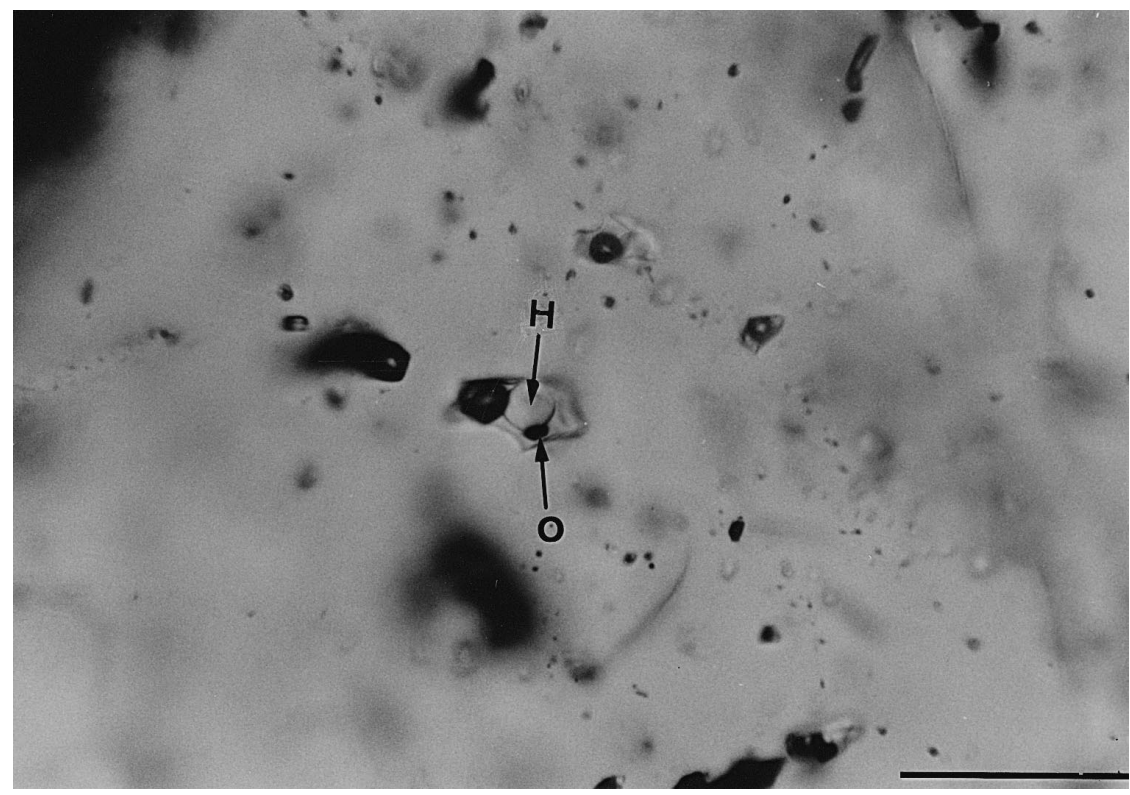

Plate 1. Photomicrograph of type IIIb fluid inclusions in sample $164(\mathrm{H}=$ halite; $\mathrm{O}=$ opaque daughter mineral). Bar scale equals $50 \mu \mathrm{m}$. 
phases at room temperature. Liquid-rich type I inclusions contain liquid + vapor \pm opaque minerals. As stated, they homogenize with vapor bubble disappearance, but are then further divided into subpopulations based on the absence (type Ia) or presence (type $\mathrm{Ib}$ ) of opaque minerals. Type $\mathrm{Ib}$ inclusions containing opaque phases are rare. Two-phase vapor-rich type II inclusions with vapor bubbles filling more than 90 vol.\% of the inclusion homogenize to vapor. Liquid-rich type III inclusions contain halite \pm additional daughter minerals at room temperature (Plate 1). Subpopulations are based on the presence or absence of opaque minerals and sylvite. Type IIIa containing liquid, vapor and halite is the typical type III inclusions. Rarely do inclusions contain either an opaque, or an opaque and sylvite. They are classified as type IIIb (liquid + vapor + halite + opaque) and type IIIC (liquid + vapor + halite + opaque + sylvite), respectively.

The majority of the inclusions in this sample are within growth zones or randomly distributed throughout the crystals and are interpreted as being primary or of pseudosecondary origin. Though type Ia inclusions are by far the most abundant, type II inclusions are also widespread. Type III inclusions are relatively rare and may concentrate in a certain area within quartz grains or occur as a single inclusion within abundant type I or type II inclusions. No definitive paragenetic relationships between the three inclusion types, though, can be observed.

Halite is the most common daughter mineral. Sylvite is identified by its rounded form, lower relief and higher thermal coefficient of solubility than halite. Most opaque solid phases are either nearly rectangular in form or so small that the shape could not be distinguished. Hematite is identified by its characteristic red color.

Fluid inclusions in sample 164 display higher homogenization temperatures (Fig. 2E). In this study, with continued heating, halite daughter minerals dissolve after vapor bubble disappearance in approximately $50 \%$ of type III inclusions; the remaining $50 \%$ homogenized with vapor bubble disappearance at temperatures above the halite dissolution temperature. Salinities are calculated from the melting temperature of halite based on Potter et al. (1977) and Chou (1987). Salinities (wt.\% $\mathrm{NaCl}$ eq.) as a function of the final homogenization temperatures for

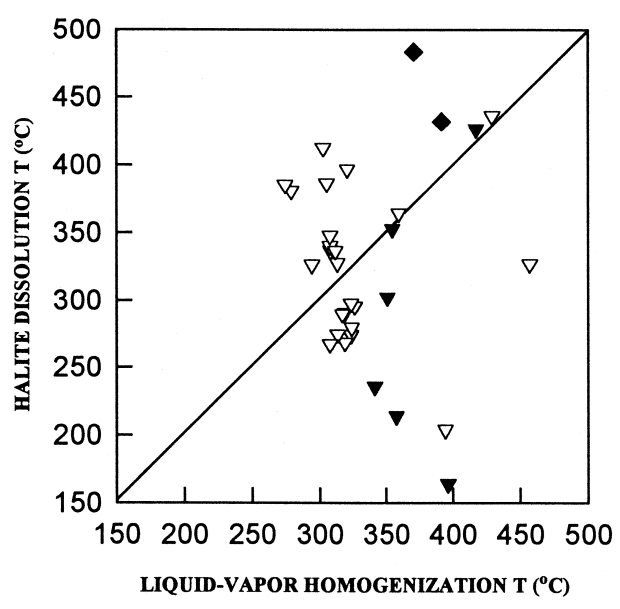

Fig. 3. Halite dissolution temperatures as a function of liquidvapor homogenization temperatures for type III inclusions. The diagonal line separates those inclusions which undergo final homogenization by halite dissolution (upper left) from those which undergo final homogenization by vapor bubble disappearance (lower right). Symbols as in Fig. 2F.

type I and type III fluid inclusions from sample 164 are shown in Fig. 2F.

Fig. 3 illustrates liquid-vapor homogenization temperatures versus halite dissolution temperatures for type III inclusions. As shown in Fig. 3, inclusions trapped to the left of the iso-Th line, which is defined by $\mathrm{Th}(\mathrm{L}-\mathrm{V})=\mathrm{Ts}$ (halite), homogenize with halite dissolution after the vapor has disappeared, while inclusions trapped to the right of the iso-Th line exhibit liquid-vapor homogenization after halite dissolution. Inclusions trapped along the iso-Th line will homogenize with the simultaneous disappearance of halite and vapor.

\section{Gas chemistry}

\subsection{Bulk analysis}

Fluid inclusion gases from the Chinkuasih hydrothermal system were analyzed with a quadrupole mass spectrometer (QMS) and a capacitance manometer. The $\mathrm{H}_{2} \mathrm{O}, \mathrm{CO}_{2}, \mathrm{~N}_{2}, \mathrm{CH}_{4}$ and Ar contents were determined quantitatively by bulk analysis, where 'bulk' refers to the average of all the inclusions decrepitated in the furnace. Sulfur gas 
Table 3

Results of bulk analyses of gases in fluid inclusions

\begin{tabular}{|c|c|c|c|c|c|c|}
\hline \multicolumn{2}{|c|}{ Sample no. 209} & 139 & 132 & 174 & 202 & 160 \\
\hline \multicolumn{7}{|c|}{ Gas contents $(\mathrm{mol} \%)$} \\
\hline $\mathrm{H}_{2} \mathrm{O}$ & 99.66 & 99.49 & 99.67 & 99.45 & 99.66 & 99.61 \\
\hline $\mathrm{CO}_{2}$ & 0.27 & 0.46 & 0.29 & 0.52 & 0.32 & 0.33 \\
\hline $\mathrm{N}_{2}$ & 0.066 & 0.044 & 0.028 & 0.026 & 0.015 & 0.049 \\
\hline $\mathrm{CH}_{4}$ & 0.0028 & 0.0015 & 0.015 & 0.0019 & 0.0016 & 0.0088 \\
\hline $\mathrm{Ar}$ & - & - & - & - & - & - \\
\hline $\mathrm{SO}_{2}$ & de. & - & - & de. & de. & - \\
\hline
\end{tabular}

de.: detected, but not quantitatively determined.

species could not be quantitatively determined because of their adsorption and reaction with the stainless steel tubing.

Six analyzed samples all contain vapor-rich inclusions which may have resulted from boiling fluids. About $0.3 \mathrm{~g}$ of the samples were pre-heated at $200^{\circ} \mathrm{C}$ for $3 \mathrm{~h}$. After the mass spectrometer system was evacuated at $4 \times 10^{-8}$ Torr for one night, measurements were started at a high heating rate in an infrared furnace. It took $3 \mathrm{~min}$ to heat samples to $500^{\circ} \mathrm{C}$.
The results of bulk analysis (Table 3 ) indicate that the inclusion fluids are mainly comprised of $\mathrm{H}_{2} \mathrm{O}$ and $\mathrm{CO}_{2}$. The concentration of $\mathrm{CO}_{2}$ ranges from $0.27 \mathrm{~mol} \%$ to $0.52 \mathrm{~mol} \% . \mathrm{N}_{2}$ is about one order of magnitude less than $\mathrm{CO}_{2}$. The $\mathrm{CH}_{4}$ content though variable, is consistently less than $\mathrm{N}_{2}$. The Ar content in all of the samples is below the detection limits. A small amount of $\mathrm{SO}_{2}$ was detected in three samples. However, the $\mathrm{SO}_{2}$ which was detected in the fluid inclusions could have been generated from $\mathrm{H}_{2} \mathrm{~S}$, and the $\mathrm{N}_{2}$ and Ar reported in the gas compositions could have also been from atmospheric contamination, rather than inclusion fluids, during QMS analysis (Graney and Kesler, 1995).

\subsection{Individual fluid inclusion analysis}

Individual fluid inclusions were analyzed semiquantitatively for 10 samples to determine the major gaseous species in the mass range from 2 to 70 . About $10 \mathrm{mg}$ of each sample was placed in the fused silica tube of the QMS. After preheating at $200^{\circ} \mathrm{C}$ for $1 \mathrm{~h}$, the sample was heated from $200^{\circ} \mathrm{C}$ to $480^{\circ} \mathrm{C}$ at a
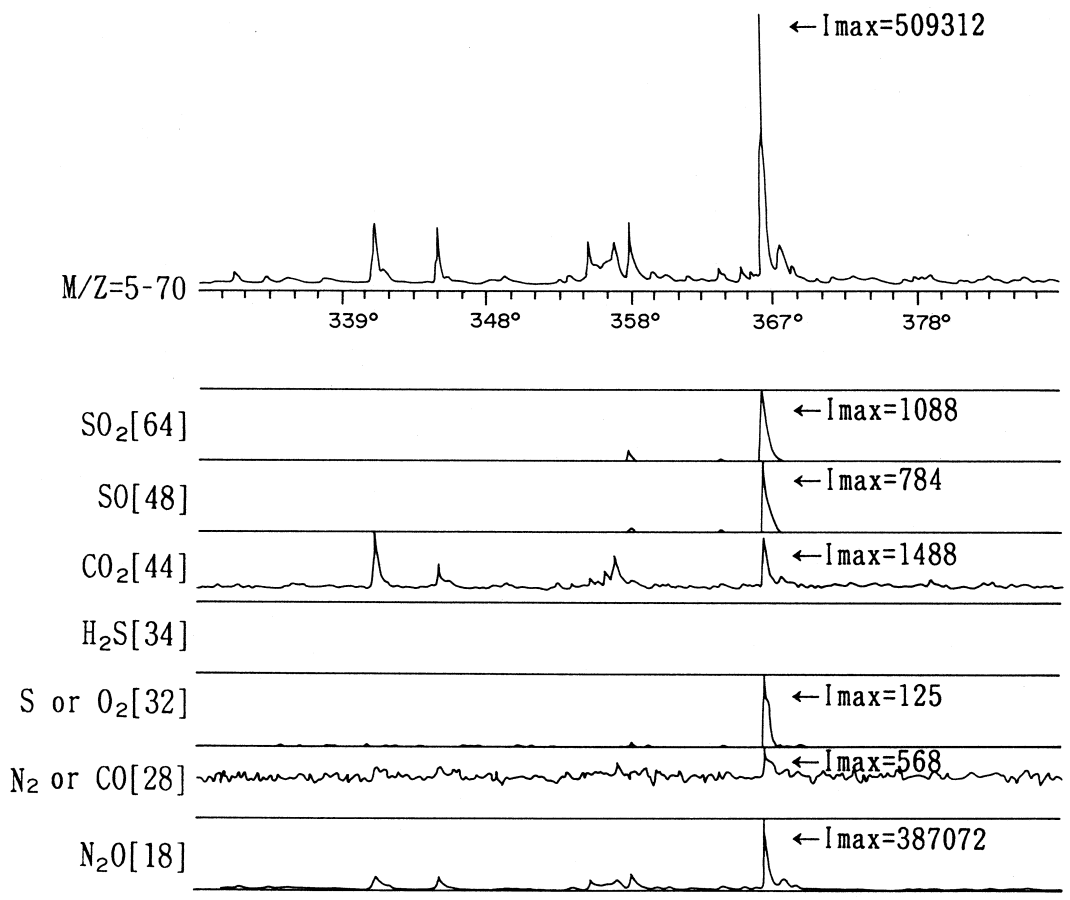

Fig. 4. Analysis of individual fluid inclusions from sample 201, Third Changjen. Eight charts represent mass spectrometer response for the major gaseous species in the mass range from 2 to 70 versus temperatures. The heating rate is $10^{\circ} \mathrm{C} / \min$. $I_{\max }$ is the maximum ion count. 
heating rate of $10^{\circ} \mathrm{C} / \mathrm{min}$. Gases were released continuously from individual decrepitated inclusions and were analyzed with a rapid-scanning quadrupole which provided very fast, continuous data acquisition. A single peak detected by the QMS is believed to correspond to the decrepitation of a single fluid inclusion. Occasionally, a larger peak burst or subordinate multiple peaks of a burst may have corresponded to a cluster of inclusions.

The results of individual fluid inclusions indicate that the fluids contain mainly $\mathrm{H}_{2} \mathrm{O}$ and small but variable amounts of $\mathrm{CO}_{2}$. Some inclusions have an unusually high $\mathrm{CO}_{2}$ content, indicative of the decrepitation of the vapor-rich inclusions which are rich in $\mathrm{CO}_{2}$. These inclusions could have been caused by the heterogeneous trapping of a two-phase boiling fluid. Significant quantities of $\mathrm{SO}_{2}$ which may have been oxidized from $\mathrm{H}_{2} \mathrm{~S}$ during the QMS analysis are also identified in some fluids. The peak height of other gas species, such as $\mathrm{CH}_{4}, \mathrm{~N}_{2}$ and $\mathrm{H}_{2} \mathrm{~S}$ are very difficult to identify due to their low concentrations. Fig. 4 shows that the $\mathrm{SO}_{2}$ peaks correspond well with those of $\mathrm{H}_{2} \mathrm{O}(M / Z=18)$, S or $\mathrm{O}_{2}(M / Z$ $=32), \mathrm{CO}_{2}(M / Z=44)$ and $\mathrm{SO}(M / Z=48)$, associated with a large burst in sample 201. The good agreement with $\mathrm{SO}_{2}, \mathrm{SO}$, and $\mathrm{S}$ or $\mathrm{O}_{2}$ indicate that some of the $\mathrm{SO}$ and $\mathrm{S}$ or $\mathrm{O}_{2}$ may have been formed by the fragmentation of $\mathrm{SO}_{2}$.

\section{Discussion}

The epithermal gold-copper deposits at Chinkuashih exhibit general features in common with typical high-sulfidation systems. These include: the tectonic setting, associated calc-alkaline volcanic rocks, acidic wall-rock alteration, ore mineral assemblages and possible association with a porphyry-type mineralization at depth. (Arribas, 1995). The evolution of the hydrothermal system consists of an early stage of acidic wall-rock alteration and a late stage of $\mathrm{Au}-\mathrm{Cu}$ mineralization. During the alteration stage, acidic $\mathrm{H}_{2} \mathrm{SO}_{4}-\mathrm{HCl}$-bearing fluids caused strong leaching of the rock, and formed the vuggy silica bodies and advanced argillic alteration zone. By analogy with other high-sulfidation systems (Hedenquist et al., 1994; Arribas et al., 1995; Rug- gieri et al., 1997), it is suggested these acidic fluids were generated by the interaction of a magmatic vapor plume which separated at depth from fluids exsolved from a crystallizing magma, with shallow waters, most probably of meteoric origin. Following the early stage of hypogene acidic alteration, $\mathrm{Au}-\mathrm{Cu}$ mineralization occurred in the shallowest parts of the central core of the hydrothermal activity, in association with hydrothermal brecciation and the deposition of amorphous silica and sulfides along open fractures or in open spaces. An underlying shallow intrusion may have provided the heat needed to drive fluid circulation and to induce phreatic and phreatomagmatic explosions which then produced the diatreme breccias. Geophysical evidence for the presence of such an intrusion at a present depth of $700 \mathrm{~m}$, in fact, was reported by Chen (1993).

Fluid inclusion data provide some information on the hydrothermal fluids circulating in the Chinkuashih epithermal system. The different fluid inclusion types and microthermometric data are similar to the fluid inclusions documented in several high-sulfidation deposits (Arribas, 1995). For example, moderate- to low-salinity fluid inclusions with $\mathrm{Th}$ mostly $<300^{\circ} \mathrm{C}$ were recorded in many high-sulfidation systems (Arribas, 1995; Mancano and Campbell, 1995; Ruggieri et al., 1997). These inclusion fluids included the main-stage fluids of epithermal high-sulfidation mineralization.

Primary type Ia inclusions in hydrothermal quartz (except sample 164) probably contain the fluid present during the deposition of pyrite or enargite coeval with euhedral hydrothermal quartz crystals lining vuggy silica fractures. This pyrite and enargite precipitated during the ore stage. Therefore, primary type Ia inclusions may represent some of fluids directly related to ore deposition. Secondary type Ia inclusions in both hydrothermal quartz and igneous quartz phenocrysts were introduced after primary type Ia inclusions, which contained the fluid related to the precipitation of the hydrothermal quartz. These primary and secondary type Ia inclusions with $\mathrm{Th}$ mostly from $190^{\circ} \mathrm{C}-280^{\circ} \mathrm{C}$ and salinities mostly from $0.5-5.0$ wt. $\% \mathrm{NaCl}$ eq., probably represent fluids related to the epithermal high-sulfidation mineralization at Chinkuashih.

In the Penshan group, the relationship between homogenization temperatures and the salinities of 
primary and secondary fluid inclusions within different quartz probably reflects a complex sequence of fluid events, such as cooling, mixing, and boiling. The trend of increasing salinities with decreasing temperatures, as observed in Fig. 2B, may be partially related to boiling because during the process, vapor loss led to an increase in the salinity in the cooling residual liquid (Hedenquist and Henley, 1985). Consequent cooling recorded by secondary inclusions may have been caused by the incursion of cold fluid, or it could have been due to a falling water table caused by uplift and erosion.

Microthermometric measurements of secondary fluid inclusions indicate that the salinities at constant $\mathrm{Th}$ in the samples from the breccia pipes of the Tsushihshan-Changjen group show a bimodal distribution. The higher salinity of the fluid cannot be attributed to dissolved gas since the results of gas bulk analysis indicate that inclusions in the samples contain a total gas content $\left(\mathrm{CO}_{2}, \mathrm{~N}_{2}\right.$, and $\left.\mathrm{CH}_{4}\right)$ of less than $0.5 \mathrm{~mol} \%$. These values are too low to have yielded significant freezing-point depressions. Nevertheless, as described by Fournier (1979), a bimodal chloride content for a certain temperature value cannot only be explained by boiling and dilution. On the contrary, some other dissolved constituents may have been added into the hydrothermal fluid. Hedenquist et al. (1992) indicated that this phenomenon may be due to the intermittent incursion of magmatic fluid at depth. However, the amount of magmatic fluid involved in the shallow level can be very small, also phreatic or phreato-magmatic.

The microthermometric characteristics and daughter phases of type III inclusions are similar to those found in many porphyry copper deposits (Roedder, 1984). For example, total salinities determined for the two inclusions that contain halite and sylvite are 58.6 wt.\% and 63.8 wt.\%, respectively. Ratios of $\mathrm{NaCl} /(\mathrm{NaCl}+\mathrm{KCl})$ are 0.75 and 0.80 (Bodnar et al., 1989), which is typical of inclusions found in porphyry systems (Roedder, 1984). Recent research has also shown that high-salinity inclusions occur in a number of high-sulfidation deposits, such as in the Nansatsu district, Japan (Hedenquist et al., 1994), Rodalquilar, Spain (Arribas et al., 1995) and Furtei, Italy (Ruggieri et al., 1997). These inclusions in high-sulfidation deposits may represent fluids of magmatic origin or the result of the mixing of mag- matic and meteoric fluids (Arribas, 1995). High-temperature, liquid-rich high-salinity (type III) inclusions coexisting with high-temperature, vapor-rich, low-salinity inclusions (type II) in sample 164 signify that these fluids may be the result of the boiling of a high-temperature liquid, or they may reflect immiscible vapor and hypersaline liquid derived from emplaced magma (Hedenquist and Lowenstern, 1994; Arribas, 1995).

Some information on pressure conditions during the evolution of the Chinkuashih epithermal system may be derived from the fluid inclusion data. In the Penshan group, the homogenization temperatures of inclusions trapped from the boiling fluid provide measures of pressure which, in turn, are also indications of the depth of deposition. On the basis of a model in which mineralization occurs from a hydrostatically pressured $\mathrm{NaCl}-\mathrm{CO}_{2}-\mathrm{H}_{2} \mathrm{O}$ fluid, total pressure at the Th was calculated according to the procedure described by Barton and Chou (1993a,b). Using the homogenization temperature of $271^{\circ} \mathrm{C}$, a salinity of 0.88 wt.\% $\mathrm{NaCl}$ eq., and a bulk $\mathrm{CO}_{2}$ determination of $0.27-0.46 \mathrm{~mol} \%$, the pressure estimate of 6.9-7.9 MPa was obtained for the Penshan orebody which corresponds to a boiling depth of 850-970 m below the surface. This estimated pressure (and therefore depth) demonstrates that the pressure of $\mathrm{CO}_{2}$ could add 200-300 m to the probable depth of inclusion trapping. It should be noted that this compares to the 5.2 MPa that was estimated by Haas (1971) from $\mathrm{CO}_{2}$-free water.

The formation pressure of hydrothermal quartz containing high-temperature high-salinity inclusions can also be obtained from the microthermometric data of these inclusions. The coeval halite-bearing and vapor-rich inclusions along growth zones and/or healed fractures which were trapped in an immiscible fluid system are $P-T$ indicators (Bodnar and Vityk, 1994). Based on petrographic observation, the inclusions that exhibit liquid-vapor homogenization between $315^{\circ} \mathrm{C}$ and $396^{\circ} \mathrm{C}$ and salinities of 30 to 42 wt. $\% \mathrm{NaCl}$ eq. are assumed to be trapped under a two-phase (immiscibility) condition. Vapor-pressures determined for these inclusions are in the range of 7.5 and 21.5 MPa (Bodnar and Vityk, 1994). The difference in pressure may indicate fluctuating pressure conditions between lithostatic and hydrostatic. These fluids at greater depth could have been trans- 
ported to the relatively shallow level by phreatic or phreato-magmatic explosion.

Yet, as emphasized in Bodnar and Vityk (1994), if the halite-bearing inclusions homogenize by halite dissolution, then the coexisting halite-bearing and the vapor-rich inclusions cannot represent an immiscible pair. A number of saline inclusions in this sample which have similar liquid-vapor homogenization temperatures but which exhibit higher halite-melting temperatures may have been trapped at similar temperatures but under greater pressure (Bodnar, 1994; Cline and Bodnar, 1994). Such conditions might have indeed occurred as the system became overpressured prior to fracturing during phreatic and phreato-magmatic explosions.

Type I inclusions in sample 164 may be caused by pressure reduction and aqueous fluid exsolution during the brecciation of the deep-seated magma and overlying rocks. At low pressure, the chlorine partition coefficient was reduced and exsolved; however, these inclusions could have formed during some later event.

As indicated by Giggenbach et al. (1990) and Giggenbach (1992), the $\mathrm{CO}_{2}$ and $\mathrm{CH}_{4}$ in the hydrothermal fluids may largely be derived from sediments, whereas, most of the $\mathrm{N}_{2}$ may be related to meteoric (atmospheric) origin. The relatively low salinity and the contents of $\mathrm{CO}_{2}, \mathrm{~N}_{2}$ and $\mathrm{CH}_{4}$ in the inclusions suggest that the inclusion fluids are prevalently meteoric waters that have reacted to varying degrees with the host rocks (Moore and Norman, 1996). The presences of $\mathrm{SO}_{2}$ (or $\mathrm{H}_{2} \mathrm{~S}$ ) in the inclusions could be induced by pnenumato-magmatic events (Giggenbach et al., 1990).

\section{Conclusions}

Fluid inclusion in quartz records the hydrothermal activity of the Chinkuashih, epithermal, high-sulfidation $\mathrm{Au}-\mathrm{Cu}$ deposits. Low-salinity fluid inclusions (0.5-5.0 wt.\% $\mathrm{NaCl}$ eq.) with homogenization temperatures mostly ranging from $190^{\circ} \mathrm{C}-280^{\circ} \mathrm{C}$ represent some of the fluids related to ore deposition. These inclusions trapped small amounts of $\mathrm{CO}_{2}, \mathrm{~N}_{2}$, $\mathrm{CH}_{4}$ and $\mathrm{SO}_{2}$ (or $\mathrm{H}_{2} \mathrm{~S}$ ). The coexistence of liquidand vapor-rich inclusions suggests boiling conditions. The inclusions were trapped at depths of
850-970 m below the water table. Microthermometric data indicate that mixing and cooling also probably occurred in the hydrothermal system, and hypersaline fluids from the deep-seated magma sometimes rose at shallower levels and mixed with meteoric water during the mineralization stage.

\section{Acknowledgements}

Special thanks are due to S.H. Chung, T.Y. Chuang, J.C. Wang and J.T. Chang for assistance with the field work and sample preparations. The authors gratefully acknowledge B.S. Yu, L.P. Tan and Chao-Hsia Chen for suggestions, information and samples. Gratitude is also extended to Takayuki Sawaki for helping with the data computation of fluid inclusion gas analysis and to Robert J. Bodnar for providing computer programs and additional information. I-Ming Chou taught Y. Wang how to calculate hydrostatic pressure and provided other information, which is gratefully appreciated.

\section{References}

Arribas, A. Jr., 1995. Characteristics of high sulfidation epithermal, and their relation to magmatic fluid. Mineralogical Assoc. Can. Short Course 23, 419-454.

Arribas, A. Jr., Cunningham, C.G., Rytuba, J.J., Rye, R.O., Kelly, W.C., Podwysocki, M.H., McKee, E.H., Tosdal, R.M., 1995. Geology, geochronology, fluid inclusions, and isotope geochemistry of the Rodalquilar Au alunite deposit. Spain Econ. Geol. 90, 795-822.

Barton, P.B., Chou, I.M., 1993a. Refinement of the evaluation of the role of $\mathrm{CO}_{2}$ in modifying estimates of the pressure of epithermal mineralization. Econ. Geol. 88, 873-881.

Barton, P.B., Chou, I.M., 1993b. Calculation of the vapor-saturated liquidus for the $\mathrm{NaCl}-\mathrm{CO}_{2}-\mathrm{H}_{2} \mathrm{O}$ system. Geochim. Cosmochim. Acta 57, 2715-2723.

Bodnar, R.J., 1993. Revised equation and table for determining the freezing point depression of $\mathrm{H}_{2} \mathrm{O}-\mathrm{NaCl}$ solutions. Geochim. Cosmochim. Acta 57, 683-684.

Bodnar, R.J., 1994. Synthetic fluid inclusions: XII. Experimental determination of the liquidus and isochores for a $40 \mathrm{wt} \%$ $\mathrm{H}_{2} \mathrm{O}-\mathrm{NaCl}$ solutions. Geochim. Cosmochim. Acta 58, $1053-$ 1063.

Bodnar, R.J., Vityk, M.O., 1994. Interpretation of microthermometric data for $\mathrm{H}_{2} \mathrm{O}-\mathrm{NaCl}$ fluid inclusions. In: De Vivo, B., Frezzotti, M.L. (Eds.), Fluid Inclusions in Minerals: Methods and Applications. Short Course of the Working Group (IMA) 'Inclusions in Minerals', September 1-4, 1994, PontignanoSiena, 117-130. 
Bodnar, R.J., Reynolds, T.J. Kuehn, C.A., 1985. Fluid inclusion systematics in epithermal systems, In: Berger, B.R., Bethke, P.M. (Eds.), Geology and Geochemistry of Epithermal Systems. Soc. of Econ Geol., Rev. Econ. Geol. 2, 73-98.

Bodnar, R.J., Sterner, S.M., Hall, D.L., 1989. SALTY: a fortran program to calculate compositions of fluid inclusions in the system $\mathrm{NaCl}-\mathrm{KCl}-\mathrm{H}_{2} \mathrm{O}$. Computers and Geosciences $15,19-$ 41.

Chen, P.Y., 1971. Occurrence and genesis of kaolin minerals from Taiwan: Part II. Dickite and nacrite. Proc. Geol. Soc. China 14, 21-33.

Chen, C.S., 1993. Application of CSAMT method for gold-copper deposits, Chinkuashih area, northern Taiwan. TAO 4, 339-350.

Chen, J.C., Huh, C.A., 1982. Geochemistry of decites from Chinkuashih area, northeastern Taiwan. Proc. Geol. Soc. China 25, 67-81.

Chen, C.H., Tan, L.P., Tien, R.L., Chung, S.H., Liu, T.K., 1993. Fission track age of igneous rocks and silicified sandstones from the Chilung volcano group, northern Taiwan: implication of mineralization events of the Chinkuashih gold-copper deposits. J. Geol. Soc. China 36, 157-174.

Chou, I.M., 1987. Phase relations in the system $\mathrm{NaCl}-\mathrm{H}_{2} \mathrm{O}$ : III. solubilities of halite in vapor-saturated liquids above $445^{\circ} \mathrm{C}$ and redetermination of phase equilibrium properties in the system $\mathrm{NaCl}-\mathrm{H}_{2} \mathrm{O}$ to $1000^{\circ} \mathrm{C}$ and 1500 bars. Geochim. Cosmochim. Acta 51, 1965-1975.

Cline, J.S., Bodnar, R.J., 1994. Direct evolution of brine from a crystallizing silicic melt at the Questa, New Mexico, Molybdenum deposit. Econ. Geol. 89, 1780-1802.

Fournier, R.O., 1979. Goechemical and hydrologic considerations and the use of enthalpy-chloride diagrams in the prediction of underground conditions in hotspring systems. J. Volcanol. Geotherm. Res. 5, 1-16.

Giggenbach, W.F., 1992. Magma degassing and mineral deposition in hydrothermal systems along convergent plate boundaries. Econ. Geol. 87, 1927-1944.

Giggenbach, W.F., Garcia, P.N., Londono, C.A., Rodriguez, V.L., Rojas, G.N., Calvache, V.M.L., 1990. The chemistry of fumarolic vapor and thermal spring discharges from the Ne-vado del Ruiz volcanic-magmatic-hydrothermal system. J. Volcanol. Geotherm. Res. 42, 13-39.

Graney, J.R., Kesler, S.K., 1995. Factors affecting gas analysis of inclusion fluid by quadrupole mass spectrometry. Geochim. Cosmochim. Acta 59, 3977-3986.

Haas, J.L. Jr., 1971. The effect of salinity on the maximum thermal gradient of a hydrothermal system at hydrostatic pressure. Econ. Geol. 66, 940-946.

Heald, P., Foley, N.K., Hayba, D.O., 1987. Comparative anatomy of volcanic-hosted epithermal deposits: acid-sulfate and adularia-sericite types. Econ. Geol. 82, 1-26.
Hedenquist, J.W., 1987. Mineralization associated with volcanicrelated hydrothermal systems in the Circum-Pacific basin. In: Horn, M.K. (Ed.), Transactions of the Fourth Circum-Pacific Energy and Mineral Resources Conference, 4th August 1986, Singapore, 513-524.

Hedenquist, J.W., Henley, R.W., 1985. The importance of $\mathrm{CO}_{2}$ on freezing point measurements of fluid inclusions: evidence from active geothermal systems and implications for epithermal ore deposition. Econ. Geol. 80, 1379-1406.

Hedenquist, J.W., Lowenstern, J.B., 1994. The role of magmas in the formation of hydrothermal ore deposits. Nature 370, 519527.

Hedenquist, J.W., Reyes, A.G., Simmons, S.F., Taguchi, S., 1992. The thermal and geochemical structure of geothermal and epithermal systems: a framework for interpreting fluid inclusion data. Eur. J. Mineral. 4, 989-1015.

Hedenquist, J.W., Matsuhisa, Y., Izawa, E., White, N.C., Giggenbach, W.F., Aoki, M., 1994. Geology, geochemistry, and origin of high sulfidation $\mathrm{Cu}-\mathrm{Au}$ mineralization in the Nansatsu district. Jpn. Econ. Geol. 89, 1-26.

Huang, C.K., 1955. Gold-copper deposits of the Chinkuashih mine, Taiwan, with special reference to the mineralogy. Acta Geologica Taiwanica 7, 1-20.

Mancano, D.P., Campbell, A.R., 1995. Microthermometry of energite-hosted fluid inclusions from the Lepanto, Philippines, high-sulfidation $\mathrm{Cu}-\mathrm{Au}$ deposit. Geochim. Cosmochim. Acta 59, 3909-3916.

Moore, J.N., Norman, D.I., 1996. Fluid-inclusion gas analyses in active geothermal systems: examples from liquid- and vapordominated fields. Sixth Biennial Pan-American Conference on Research on fluid inclusions, Abstracts, 92-94.

Potter, R.W. II, Babcock, R.S., Brown, D.L., 1977. A new method for determining the solubility of salts in aqueous solutions at elevated temperature. J. Res. U.S. Geol. Surv. 5, 389-395.

Roedder, E., 1984. Fluid inclusions. Mineralogical Soc. Am., Rev. Mineral. 12, 646.

Ruggieri, G., Lattoazi, P., Luxoro, S., Dessi, R., Benvenuti, M., Tunelli, G., 1997. Geology, mineralogy, and fluid inclusion data of the Furtei high-sulfidation gold deposit, Sardinia, Italy. Econ. Geol. 92, 1-19.

Sasada, M., Sawaki, T., Takeno, N., 1992. Analysis of fluid inclusion gases from geothermal systems, using a rapid-scanning quadrupole mass spectrometer. Eur. J. Mineral. 4, 895906.

Tan, L.P., 1991. The Chinkuashih gold-copper deposits. Taiwan Soc. Econ. Geol. Newslett. 7, 22-24.

Wang, Y., 1973. Wall rock alteration of late Cenozoic mineral deposits in Taiwan. Acta Geol. Taiwan 16, 1-30.

Yu, B.S., 1994. Auriferous breccia pipes of Chinkuashih, Taiwan. $\mathrm{PhD}$ thesis, National Taiwan University, 322 pp. (unpubl.). 